\title{
Further studies on the problem of goitre in Ceylon
}

\author{
By K. MAHADEVA, D. A. SENEVIRATNE AND D. B. JAYATILLEKE \\ Department of Nutrition, \\ AND S. SENTHE SHANMUGANATHAN, P. PREMACHANDRA \\ AND M. NAGARAJAH \\ Department of Biochemistry, Medical Research Institute, Colombo, Ceylon
}

$$
\text { (Received } 4 \text { September 1967-Accepted } 3 \text { May 1968) }
$$

\footnotetext{
I. A comparative study of the iodine and calcium contents of diets in areas of Ceylon where goitre is endemic and non-endemic was carried out.

2. The iodine content of food grown in non-endemic areas was, in most instances, considerably higher than in endemic areas.

3. In endemic areas the daily average intake per person per day was well above the allowance of roo-150 $\mu \mathrm{g}$ recommended by most workers. The critical level of total daily iodine intake below which goitre becomes endemic in Ceylon was $400 \mu \mathrm{g}$. Possible reasons for this higher need of iodine are discussed.

4. Addition of iodine to cooking salt has been used successfully to combat endemic goitre in many countries. The amount of iodine added is based on the degree of endemicity and the amount of salt consumed per person per day. It is suggested that the more important criteria which should determine the amount of iodine added to cooking salt are the dietary iodine content, the daily total intake of dietary iodine and particularly the level of iodine below which goitre becomes prevalent.
}

An earlier study (Mahadeva \& Senthe Shanmuganathan, 1967) on the aetiology of endemic goitre in Ceylon showed that the heavy annual rainfall followed by a high annual escape from the river basins into the sea leached the soil of its soluble minerals and this appeared to be reflected in the iodine contents of the foodstuffs grown in these areas.

In this investigation a comparative study of the iodine and calcium content of foods locally grown in endemic and non-endemic areas was carried out. The results were used to evaluate the total intake of iodine and calcium per person per day. The findings indicate that the iodine content of foods grown in non-endemic areas is, in most instances, considerably higher than in the same food grown in endemic areas and that even in the latter areas the daily average intake of iodine per person per day is well above the allowance of I00-I $50 \mu \mathrm{g}$ recommended (Greenwald, I955; Davidson \& Passmore, 1965). There appears to be no consistent difference between the calcium contents of the foods grown in the endemic and non-endemic areas.

\section{EXPERIMENTAL}

Three villages, Wetera, Pothupitiya and Uluvitike, where goitre is endemic and a village in Jaffna, a non-endemic area (Mahadeva \& Senthe Shanmuganathan, 1967), were selected for the study. Wetera, where the incidence of goitre is highest, and Pothupitiya, a village on the sea coast, are situated in the Western Province and Jaffna is in the Northern Province of Ceylon (Fig. I). 
The composition and average intake of food by an adult per day in the rural areas of Ceylon were obtained from the results of previous studies (Gunasekara, 1958; Mahadeva \& de Silva, 1962-3) incorporating seven villages, 219 households and I 266 subjects (Table I). On the basis of their origin the items of food which constitute the normal diet of the people in the areas chosen for the study were classified into three

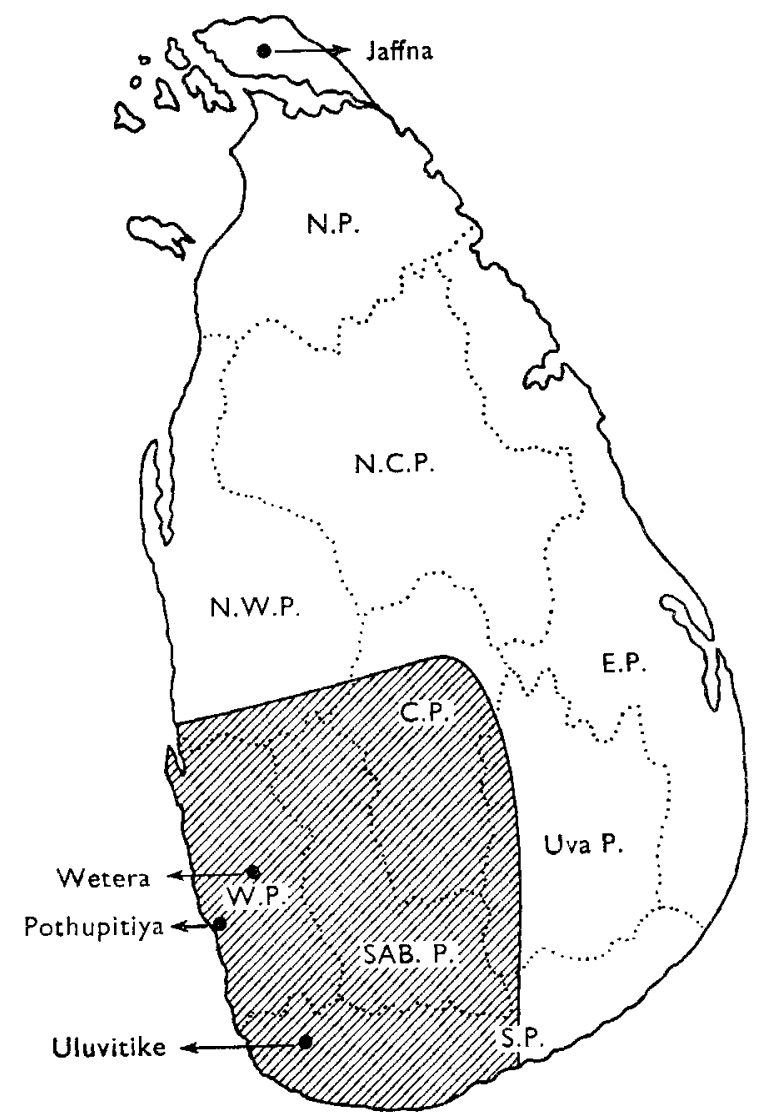

Fig. I. The areas in Ceylon where goitre is endemic $(\square)$ and non-endemic $(\square)$. Provinces are marked by abbreviations: N.P., Northern Province; N.C.P., North Central Province; N.W.P., North Western Province; C.P., Central Province; S.P., Southern Province, E.P.; Eastern Province; SAB.P., Sabaragamuwa Province; Uva P., Uva Province; W.P., Western Province.

categories for the purpose of this investigation. The categories were: (I) foodstuffs locally produced in each village, e.g., cereals, pulses, leafy and fruit vegetables, ripe fruits and coconuts; (2) imported foodstuffs, e.g., wheat, sugar, dried fish; (3) foodstuffs produced in Ceylon but not necessarily in the areas under study, e.g. eggs, tea, dried fish and salt.

Items belonging to categories 2 and 3 were therefore obtained in Colombo for the assay of iodine and calcium. Items belonging to category, $x$, i.e. the foodstuffs locally produced, were obtained from each of the four villages. To make direct comparison of 
the results possible, only those foods that could be grown in all parts of the island and that were also available at the four villages were collected for analysis.

The iodine content of these foodstuffs was determined by the method of Borst Panwels \& van Wesemael (I962). The iodine contents of each item of food, in the leafy and fruit-vegetable groups, were combined and an average obtained because these two groups are normally heterogeneous. The total intake of iodine per person per day in each of the four areas was then estimated. The iodine contents of the different items of food are shown in Table 2. The average quantity of drinking water consumed per adult per day was determined for twenty subjects in each area and amounted to $\mathrm{I} 1$./day. The iodine content of the water in these areas is available from an earlier study (Mahadeva \& Senthe Shanmuganathan, r967).

The iodine content of each of five vegetables, leafy and fruit, which were easily obtainable, was determined before and after cooking. For cooking the following procedure was adopted. A sample of $20 \mathrm{~g}$ of the cleaned and chopped vegetable was suspended in 50-100 $\mathrm{ml}$ of distilled water and boiled till the vegetable was fully cooked. The resultant cooked vegetable including the extracts were dried in a hot oven at 100-10 $5^{\circ}$ to constant weight. The iodine losses were then determined for each vegetable.

The calcium content of these foodstuffs was determined by the method of King \& Wootton (1956). The total intake of calcium per person per day was determined in the same manner as the total intake of iodine.

\section{RESULTS}

The average food consumption in $\mathrm{g}$ per person per day in rural areas of Ceylon is given in Table $\mathbf{I}$.

The iodine content of foodstuffs for each area is shown in Table 2. It will be seen that, with one exception, brinjal (Solanum melongena L.; aurbergines), the iodine

Table I. Average food consumption ( $g$ per person per day) in rural areas of Ceylon

$\begin{array}{lr}\text { Cereal } & \\ \text { Country rice } & 283.5 \\ \text { Rice flour } & 28 \cdot 4 \\ \text { Bread } & 28 \cdot 4 \\ \text { Wheat flour } & 28 \cdot 4 \\ \text { Pulse } & 28 \cdot 4 \\ \text { Leafy vegetable } & 28 \cdot 4 \\ \text { Fruit vegetable } & \\ \quad \text { Vegetable fruits, in- } & 85.0 \\ \quad \text { cluding jak, bread- } & \\ \text { fruit, gourds and } & \\ \text { pumpkins } & \\ \text { Ripe fruits } & \\ \text { Nuts, coconut } & \end{array}$

Fish

$\begin{array}{lc}\text { Dried fish } & 28 \cdot 4 \\ \text { Others } & \\ \text { Green chilli } & 2 \cdot 8 \\ \text { Lime juice } & 2 \cdot 0 \mathrm{ml} \\ \text { Curry powder } & 28 \cdot 4 \\ \text { Sugar } & 42 \cdot 5 \\ \text { Tea } & 4 \cdot 7 \\ \text { Salt } & 7 \cdot \mathrm{I} \\ \text { Water } & \text { Il. }\end{array}$

content of all the foodstuffs grown in Jaffna in the Northern Province, a non-endemic area, was considerably higher than those in the three villages in the endemic areas of the Western and Southern Provinces. These findings confirm an observation made in 
an earlier paper (Mahadeva \& Senthe Shanmuganathan, 1967) that the iodine content of the subsoil water may be reflected in the foodstuffs grown in the area. The iodine content of the subsoil water was shown to be influenced by the degree of leaching of soluble minerals following heavy rainfall.

Table 2. Iodine contents of foodstuffs from five areas in Ceylon ( $\mu \mathrm{g} / \mathrm{I} 00 \mathrm{~g}$ wet weight)

\begin{tabular}{|c|c|c|c|c|c|}
\hline \multicolumn{6}{|c|}{ Pothupitiya } \\
\hline Rice, country & - & $2 I \cdot 0$ & $9 \cdot 8$ & $4 \cdot 3$ & $88 \cdot 0$ \\
\hline Bread & $6 \cdot 7$ & - & $\ldots$ & - & - \\
\hline Wheat flour & $8 \cdot 7$ & - & - & - & - \\
\hline \multicolumn{6}{|l|}{ Pulse } \\
\hline $\begin{array}{l}\text { Green gram (Phaseolus } \\
\text { mungo var. radiatus) }\end{array}$ & - & $2 \cdot 2$ & $8 \cdot 0$ & $26 \cdot I$ & $88 \cdot 0$ \\
\hline \multicolumn{6}{|l|}{ Leafy vegetables } \\
\hline Kankun (Ipomoea reptans) & - & $39^{\circ} \circ$ & - & - & - \\
\hline $\begin{array}{l}\text { Kathurumurunga (Sesbania } \\
\text { grandiflora) }\end{array}$ & - & 17 & - & - & $45 \cdot 0$ \\
\hline $\begin{array}{l}\text { Mukunuwenna (Alternan- } \\
\text { thera sessilis) }\end{array}$ & - & $6 \cdot 0$ & $2,4^{\circ} 0$ & 0.8 & - \\
\hline \multicolumn{6}{|l|}{ Fruit vegetables } \\
\hline $\begin{array}{l}\text { Bandakka (Hibiscus } \\
\text { esculentus) }\end{array}$ & - & - & - & - & $3 \cdot 0$ \\
\hline $\begin{array}{l}\text { Brinjal (Solanum } \\
\text { melongena) }\end{array}$ & - & $72 \cdot 0$ & 5.0 & 0.5 & $33 \cdot 0$ \\
\hline $\begin{array}{l}\text { Ash plantain (Musa } \\
\text { paradisiaca) }\end{array}$ & - & 2.5 & $2 \cdot 2$ & $15 \cdot 3$ & $67 \cdot 5$ \\
\hline Murunga (Moringa oleifera) & - & - & - & - & $3 \cdot 5$ \\
\hline $\begin{array}{l}\text { Breadfruit (Artocarpus } \\
\text { communis) }\end{array}$ & - & $2 \cdot 5$ & - & $1 \cdot 4$ & $46 \cdot 0$ \\
\hline $\begin{array}{l}\text { Pathola (Trichosanthes } \\
\text { anguina) }\end{array}$ & - & - & - & $3 \cdot 0$ & - \\
\hline \multicolumn{6}{|l|}{ Fruit, ripe } \\
\hline \multicolumn{6}{|l|}{ Nut } \\
\hline Coconut & - & $107 \cdot 5$ & 107.5 & $132 \cdot 5$ & x66.0 \\
\hline \multicolumn{6}{|l|}{ Fish } \\
\hline Dried fish (average) & $36 \cdot 7$ & - & - & - & - \\
\hline \multicolumn{6}{|l|}{ Others } \\
\hline Chilli, green & - & $12 \cdot 0$ & $5 \cdot 0$ & $42 \cdot 0$ & 25.5 \\
\hline Lime juice & - & - & $\operatorname{Tr}$ & $\operatorname{Tr}$ & $\operatorname{Tr}$ \\
\hline Curry powder & - & I8.8 & $84 \cdot 7$ & $4 \cdot 4$ & $98 \cdot 0$ \\
\hline Sugar & 300.0 & - & - & - & - \\
\hline Tea & $178 \cdot 0$ & - & - & - & - \\
\hline Salt & $8 \cdot 5$ & - & - & - & - \\
\hline Water (per 1.) & - & 44 & $4 \cdot 4$ & $4 \cdot 6$ & 182.0 \\
\hline
\end{tabular}

$$
\text { Tr, trace. }
$$

Although the iodine contents of foods in endemic areas were considerably lower than in non-endemic areas, there appeared to be no definite trend amongst the different vegetables in the endemic areas. Several factors may be responsible for this. Thus, the food items used in the estimations were obtained from different situations in each of the four villages depending on their availability. It is possible that the degree of weathering and the leaching of the subsoil of iodine varies from place to place even in 
the same village. This could produce aberrations in individual iodine contents without affecting the general trend shown in the endemic and non-endemic areas.

The total intake of iodine per person per day in the four villages is shown in Table 3 . The critical level of total iodine intake below which goitre seems endemic may be said to be $400 \mu \mathrm{g}$. The iodine losses of five vegetables after cooking are given in Table 4 . It is possible that during the evaporation of the resulting suspension of cooked vegetables to dryness some of the free iodide may have been lost. Our estimated loss of $38 \%$ is probably an extreme figure. The calcium content of each item of food and the total intake of calcium per person per day in the four villages did not show any consistent difference (Table 5).

\begin{tabular}{|c|c|}
\hline Area & I intake \\
\hline $\begin{array}{c}\text { Goitre: Pothupitiya } \\
\text { Wetera } \\
\text { Uluvitike }\end{array}$ & $\begin{array}{l}300 \\
350 \\
300\end{array}$ \\
\hline Non-goitre: Jaffna & $85^{\circ}$ \\
\hline
\end{tabular}

Table 4. Iodine content of vegetables before and after cooking $(\mu g /$ roo $g$ wet weight $)$

\begin{tabular}{llccc} 
Local name & \multicolumn{1}{c}{ Botanical name } & Before & After & $\begin{array}{c}\text { Loss } \\
(\%)\end{array}$ \\
Tampala & Amaranthus gangeticus & $4 \cdot 4$ & $3 \cdot \mathrm{I}$ & 30 \\
Nivithi & Spinacea cleracea & $3 \cdot 9$ & $3 \cdot 0$ & 23 \\
Mukunuwenna & Alternanthera sessilis & $5 \cdot 7$ & $4 \cdot 0$ & 30 \\
Brinjal & Solanum melongena & $4 \cdot 0$ & $1 \cdot 9$ & $5 \mathrm{I}$ \\
Bitter gourd & Momordica charantia & $3 \cdot 2$ & $1 \cdot 2$ & 62 \\
$\quad$ Mean & & & & 38
\end{tabular}

\section{DISCUSSION}

The present investigation shows, quite surprisingly, that the iodine content of the food of people even in areas where goitre is endemic is about $300-350 \mu$ g per person per day. Even after allowing for extreme losses amounting to $38 \%$ which may occur during cooking, the daily intake of iodine in these areas is I 86-2 I $5 \mu \mathrm{g}$ per person per day, whereas the daily iodine content of the food in Jaffna, in the non-endemic area, is about $85^{\circ} \mu \mathrm{g}$ per day (uncorrected), or an intake of approximately $530 \mu \mathrm{g}$ per day after allowing for extreme losses during cooking. Though there is some uncertainty regarding the optimum requirements for iodine, this figure is well above the amount of iodine that is generally accepted as the normal daily requirement. Thus Greenwald (I955) is of the opinion that the requirement probably does not exceed roo $\mu \mathrm{g}$ per day and Davidson $\&$ Passmore ( $\mathrm{I}_{96} \mathrm{6}_{5}$ ) also quote the same value as having been recommended by the Nutrition Committee of the British Medical Association.

It is clear that the allowance of $100 \mu \mathrm{g}$ per person per day recommended by many authorities is not applicable to Ceylon, where the critical level for the total iodine content of the food consumed daily, below which goitre becomes endemic, is $400 \mu \mathrm{g}$, 
Table 5. Calcium content of foodstuffs in Ceylon ( $\mathrm{mg} / \mathrm{1} 00 \mathrm{~g}$ wet weight)

\begin{tabular}{|c|c|c|c|c|c|}
\hline Cereals ${ }^{\text {Foodstuff }}$ & Colombo & Wetera & Pothupitiya & Uluvitike & Jaffna \\
\hline Rice, country & - & - & $12 \cdot 2$ & $10 \cdot 3$ & 0.2 \\
\hline Bread & $14 \cdot 8$ & - & - & - & - \\
\hline Wheat flour & 15.5 & - & - & - & - \\
\hline \multicolumn{6}{|l|}{ Pulses } \\
\hline $\begin{array}{l}\text { Green gram (Phaseolus } \\
\text { Mungo var. radiatus) }\end{array}$ & - & $91^{\circ} \cdot 4$ & $95 \circ 0$ & $109 \cdot 8$ & $83 \cdot 6$ \\
\hline \multicolumn{6}{|l|}{ Leafy vegetables } \\
\hline Kankun (Ipomoea reptans) & - & $80 \cdot 5$ & - & - & - \\
\hline $\begin{array}{l}\text { Kathurumurunga (Sesbania } \\
\text { grandiflora) }\end{array}$ & - & $169 \cdot 8$ & - & - & $795^{\circ} \circ$ \\
\hline $\begin{array}{l}\text { Mukunuwenna (Altern- } \\
\text { anthera sessilis) }\end{array}$ & - & $159^{\circ} 9$ & $106 \cdot 3$ & $167 \cdot 7$ & - \\
\hline \multicolumn{6}{|l|}{ Fruit vegetables } \\
\hline $\begin{array}{l}\text { Bandakka (Hisbiscus } \\
\text { osculentus) }\end{array}$ & - & - & - & - & $103 \cdot 1$ \\
\hline $\begin{array}{l}\text { Brinjal (Solanum } \\
\text { melongena) }\end{array}$ & 一 & $26 \cdot 6$ & $16 \cdot 6$ & $6 \cdot 4$ & $7 \cdot \mathrm{I}$ \\
\hline $\begin{array}{l}\text { Ash plantain (Musa } \\
\text { paradisiaca) }\end{array}$ & - & $9 \cdot 7$ & $3 \cdot 5$ & $6 \cdot 4$ & $16 \cdot 6$ \\
\hline Murunga (Moringa oleifera) & - & - & - & - & $23 \cdot 3$ \\
\hline $\begin{array}{l}\text { Breadfruit (Artocarpus } \\
\text { communis) }\end{array}$ & - & 3377 & - & $18 \cdot 7$ & $84 \cdot 0$ \\
\hline $\begin{array}{l}\text { Pathola (Trichosanthes } \\
\text { anguina) }\end{array}$ & - & - & - & II.7 & - \\
\hline $\begin{array}{l}\text { Fruit, ripe } \\
\text { Plantain }\end{array}$ & Fruit, ripe & $2 \cdot 8$ & 15.9 & $16 \cdot 9$ & $20 \cdot 5$ \\
\hline \multicolumn{6}{|l|}{ Nuts } \\
\hline Coconut & 18.9 & - & - & - & - \\
\hline \multicolumn{6}{|l|}{ Fish } \\
\hline Dried fish (average) & - & $707 \cdot 3$ & $1896 \cdot 0$ & $271 \cdot I$ & ror $6 \cdot 0$ \\
\hline \multicolumn{6}{|l|}{ Others } \\
\hline Chilli, green & - & $29 \cdot 2$ & 35.7 & 35.7 & \\
\hline Lime juice & - & $\mathrm{Tr}$ & $\operatorname{Tr}$ & $\mathrm{Tr}$ & $\operatorname{Tr}$ \\
\hline Curry powder & - & $484: 7$ & $362 \cdot 5$ & $377 \cdot 6$ & $426 \cdot 2$ \\
\hline Sugar & - & - & - & - & - \\
\hline Tea & $324 \cdot 5$ & - & - & - & - \\
\hline Salt & $498 \cdot 0$ & - & - & - & - \\
\hline \multirow[t]{2}{*}{$\begin{array}{l}\text { Total Ca intake (mg/ } \\
\text { person day) }\end{array}$} & - & 500 & 800 & 360 & 770 \\
\hline & & & & & \\
\hline
\end{tabular}

i.e. equivalent to an iodine intake of about $240 \mu \mathrm{g}$ per day when a correction is made for losses during cooking. The iodine content of individual food items grown in the Northern Province is also consistently higher than that of the same foods grown in endemic villages in the Western and Southern Provinces.

The proximity to the sea and the consequent consumption of sea food, which is regarded as a rich source of iodine, does not appear to be an effective factor in the control of goitre in Pothupitiya, a coastal village. Other factors, such as the leaching of iodine from the soils by heavy rainfall, discussed in an earlier paper (Mahadeva \& Senthe Shanmuganathan, 1967 ), appear more important factors in the aetiology of endemic goitre. 
There are no consistent differences in the calcium contents of the various foods and in the total intake of calcium in endemic and non-endemic areas.

Various factors modify the human requirements for iodine and the possibility of any of these being responsible for the need for larger quantities of iodine by the Ceylonese people needs consideration. It is known that hard water increases the requirements for iodine (Murray, Ryle, Simpson \& Wilson, I948) but hard water is found mainly in northern Ceylon, where there is no endemic goitre, whereas the water is soft in southern Ceylon (Chanmugam, $195 \mathrm{I}$ ), where goitre is most prevalent. However, the iodine in drinking water in endemic areas contributes very little to the normal iodine intake. Nevertheless, as was suggested in an earlier study (Mahadeva \& Senthe Shanmuganathan, 1967), the iodine level of water appears to influence the iodine content of locally grown foods.

It is evident from Table I that rice and its products constitute a major part of the diet among Ceylonese. The main sources of iodine in the diet are rice, pulses, dried fish and coconut. Coconut, which is a widely used commodity, is commonly scraped and the milk extracted by squeezing with water; the milk is then incorporated in many preparations with roasted and ground spices ('curry powder'). Scraped coconut per se is used to a lesser extent in some dishes. Though the iodine requirements may be met by using foods with a higher iodine content, such manipulations of the diet are likely to upset the balance of other nutrients; in any event this is not likely to be accepted by the people, as it most certainly would cause a change in the customary dietary patterns.

Addition of iodine to cooking salt has been used successfully to combat endemic goitre in various parts of the world. However, the amount of iodine added is based only on the degree of endemicity and the quantity of salt consumed per person per day (Sooch \& Ramalingaswami, 1965). Though various countries have different quantities of iodine added to salt, most if not all additions have been designed to provide only roo- $150 \mu \mathrm{g}$ of iodine per person per day. This method has several drawbacks. First, the average consumption of salt is worked out on the basis of the total output and sale of salt. However, this includes salt that is used in industry, and an unrealistic value is obtained for salt intake. Thus, in Ceylon, although a figure of $\mathrm{I}_{5} \mathrm{~g}$ of salt is generally quoted as the quantity consumed (personal communication, Salt Commissioner), the actual amount consumed is about $7 \mathrm{~g}$ per person per day (K. Mahadeva, unpublished observation). Another source of error in the estimation of salt consumed, which is generally overlooked, arises because of the habit of discarding the first solution obtained when water is added to salt. This custom, which is prevalent particularly in southern Ceylon, arises from the fact that salt is added in the form of a solution to the food during the cooking process. Since the crude salt available in the market normally contains some amount of impurity which manifests itself as a scum in solution, the first washing is discarded. Because of this practice, addition of iodine by spraying crude salt with iodine or iodate will not ensure that the calculated amount of iodine will be actually consumed.

Secondly, as is obvious from the present study, the critical level of daily iodine intake below which endemic goitre becomes a problem can vary widely from place to 
place and a programme of addition of iodine to salt designed to provide only $100-I_{50} \mu \mathrm{g}$ iodine per day may be insufficient to combat endemic goitre. It is suggested that proper measures for the control of endemic goitre in any country can be planned only on the basis of adequate information gained from a study of the dietary iodine contents, daily total intake of dietary iodine, and particularly the level of iodine below which goitre becomes prevalent.

Though this is only a preliminary study which covers certain selected food items, the general pattern of iodine content and intake seems to be clear. More comprehensive studies on similar lines are necessary to determine whether these conclusions, which should be regarded as only tentative, are generally applicable.

\section{REFERENCES}

Borst Pauwels, G. W. F. H. \& van Wesemael, J. C. (1962). Analytica chim. Acta 26, 532.

Chanmugam, W. R. (195r). Proc. Ceylon Ass. Advmt Sci. Seventh Annual Sessions, part 3, p. 5.

Davidson, S. \& Passmore, R. (1965). Human Nutrition and Dietetics, 3rd ed., p. 254. Edinburgh and London: E. and S. Livingstone Ltd.

Greenwald, I. (1955). Am. F. clin. Med. 3, 2 r 5.

Gunasekara, D. B. (1958). Ceylon \%. Sci. 9, ro7.

King, E. J. \& Wootton, I. D. P. (1956). Micro-analysis in Medical Biochemistry, 3rd ed. pp. 77, I03. London: J. and A. Churchill Ltd.

Mahadeva, K. \& de Silva, W. A. B. (1962-3). F. Ceylon publ. Hith Ass. 3 and 4, 35.

Mahadeva, K. \& Senthe Shanmuganathan, S. (1967). Br. \%. Nutr. 21, 341.

Murray, M., Ryle, J. A., Simpson, B. W. \& Wilson, D. C. (I948). Med. Res. Coun. Memo. no. 18, p. 35.

Sooch, S. S. \& Ramalingaswami, V. (1965). Bull. Wld Hlth Org. no. 32, p. 229. 